\title{
Good Corporate Governance dan
}

\section{Manajemen Keuangan dalam Ekonomi Syariah}

\author{
Syafrudin Arif Marah Manunggal \\ Syammam.nb@gmail.com \\ Universitas Islam Negeri Yogyakarta
}

\begin{abstract}
:
The Good Corporate Governance (GCG) facing challenges to Islamic banks nowadays not only in Indonesia but also in the entire world. GCG is necessary to the Islamic banks due to significance of the stakeholders trust towards Islamic banks its self. But in practice, the GCG could serve as an obligatory and formal instrument for delivering transparant public financial reports of the Islamic banks. In avoiding its shortage of application, Islamic finance management gives guide for encountering the formalistic condition of the GCG of the Islamic banks. For the GCG and the Islamic financial management both are very important, this paper discusses a likely convergence between both principle. Finally, the GCG has to be applied by guiding the Islamic financial management. The Islamic financial management is something to do with weather the religious normative assumptions and social economic ones.
\end{abstract}

Kata kunci: GCG, management, convergence, Islamic bank.

\begin{abstract}
Abstrak:
Bank syariah saat ini menghadapi tantangan dalam hal tata kelola yang baik bagi perusahaan atau Good Corporate Governance (GCG), tidak hanya di Indonesia tetapi juga di seluruh dunia. GCG diperlukan bagi bank syariah, karena pentingnya kepercayaan para stakeholder terhadap bank syariah itu sendiri. Bahkan dalam prakteknya, GCG bisa berfungsi sebagai instrumen wajib dan formal untuk memberikan laporan keuangan publik secara transparan dari bank syariah. Dalam rangka menghindari kekurangan bank syariah dalam penerapan GCG, manajemen keuangan Islam memberikan panduan untuk menghadapi kondisi formalitas dari GCG bank-bank syariah. Jadi GCG dan manajemen keuangan syariah keduanya sangat penting. Makalah ini membahas kemungkinan konvergensi antara prinsip keduanya. Akhirnya, GCG harus diterapkan dengan cara membimbing manajemen keuangan syariah. Manajemen keuangan syariah adalah sesuatu yang harus dilakukan dengan disertai iklim asumsi normatif religius dan juga ekonomi sosial.
\end{abstract}

Kata kunci: GCG, Manajemen, konvergensi, perbankan syariah

\section{Pendahuluan}


Perbankan syariah telah melewati lebih dari empat dekade, hingga dapat berkembang luas ke seluruh dunia. Pada akhir 2011, menurut data statistik Bank Indonesia, di Indonesia sudah berdiri bank umum syariah sebanyak 11, bank konvensional dengan unit usaha syariahnya sebanyak 23. Sedangkan koperasi syariah sampai pada tahun 2005, melalui PINBUK ICMI berhasil memfasilitasi pengembangan lebih dari 3.874 BMT di seluruh Indonesia (http://www.scribd.com/doc/53721584/Makalah-pinbuk, hlm. 12). Di seluruh dunia, hingga pada tahun 1997, telah ada 176 Bank Syariah yang menyebar di berbagai negara (Lewis dan Algaoud, 2001: 227). Pada tahun 2001, Bank syariah tersebar di lebih dari 70 negara, antara lain bisa disebutkan: Australia, Bahama, Kanada, Kepulauan Cayman, Denmark, Guernsey, Jersey, Luxemburg, Irlandia, Swiss, Inggris, Amerika Serikat, Kepulauan Virginia. Khusus di tiga Negara, yaitu Pakistan, Iran, dan Sudan, bank syariah merupakan satu-satunya sistem perbankan di dalam negara tersebut (Lewis dan Algaoud, 2001: 15, 25).

Fakta sejarah bahwa perbankan Islam dilahirkan dari teori bank bebas-bunga atau interestless banking/interest-free bank (Khan, 1994: 79). Teori ini pula yang menjadi pemicu kemunculan ekonomi syariah hingga sekarang (Siddiqi, tt: 31). Kemudian teori pengganti bunga adalah teori bagi hasil atau profit-and-loss sharing/PLS (Saeed, 2003: 136). Bagi hasil berasal dari bentuk perjanjian Arab Islam yang sudah ada sebelum kenabian dan digunakan kemudian oleh Nabi. Nama bentuk perjanjian Arab Islam itu adalah mud\{a>rabah dan musha>rakah. Karena itu, penggantian bunga dengan bagi hasil menjadi falsafah bank syariah sebagai sistem intermediasi keuangan modern alternatif (Chapra, 2000: 266).

Istilah Bagi hasil itu sendiri dalam bahasa Indonesia berarti pemberian bagianbagian dari perolehan suatu usaha kepada dua mitra usaha atas keikutsertaan modal dan kerja pengelolaan yang diberikan oleh masing-masing pihak. Secara rinci, pengertian kata hasil menunjuk pada perolehan atau pendapatan. Di sana diterangkan juga bahwa Bagi hasil terjadi dalam lingkup kehidupan pertanian, lihat hlm. 64. Dari Istilah bahasa Indonesia itu, Bagi hasil dapat mengandung pengertian bagi-perolehan atau revenue sharing, bagi untung-rugi atau profit-and-loss sharing, dan bagi untung atau profit sharing (KBBI, 1989: 64 dan 300). 
Seiring dengan perkembangan bank syariah yang pesat itu, penerapan Good Corporate Governance (GCG) di lembaga perbankan syariah merupakan keniscayaan yang mendesak. Ada harapan supaya bank-bank syariah tampil sebagai "lembaga keuangan modern yang menjadi teladan dan terpercaya." Pelaksanaan GCG merupakan tuntutan bagi semua lembaga keuangan publik, terlebih untuk negara, di seluruh dunia. Di samping itu, tuntutan itu lahir dari kesamaan nilai yang melekat antara pada GCG dan kesyariahan dalam Perbankan Syariah. GCG juga bagian dari "cetak biru" dalam pengembangan perbankan syariah di Indonesia oleh Bank Indonesia, Arsitektur Perbankan Indonesia (API) dan Arsitektur Sistem Keuangan Indonesia (ASKI) maupun international best practices yang dirumuskan lembaga-lembaga keuangan syariah internasional, seperti IFSB (Islamic Financial Services Board), AAOIFI dan IIFM. Jadi GCG telah menjadi isu internasional dalam pengembangan perbankan syariah.

Ketika bank syariah dapat berkembang luas secara internasional, maka apa sebenarnya yang menjadikan GCG penting bagi perbankan syariah. Apakah Manajemen Keuangan Syariah yang telah digunakan Perbankan Syariah tidak memadai sebagai nilai sekaligus instrumen pengembangan Perbankan Syariah kedepan. Mungkinkah paradigma GCG menggeser implementasi Manajemen Keuangan Syariah. Terkait dengan hal itu, lebih tepatnya tulisan ini akan memaparkan konvergensi yang terealisir dalam pengembangan perbankan syariah di masa yang akan datang.

\section{Sejarah dan Sistem Perbankan Syariah di Indonesia}

Di Indonesia, praktek ekonomi Islam/syariah, khususnya perbankan syariah lahir karena adanya dukungan pemerintah Orde Baru di tangan Presiden Soeharto terhadap sekelompok Muslim yang menjadi penggiat ekonomi syariah pada 1992, dengan berdirinya Bank Muamalat Indonesia (BMI). Bukan berarti tiga puluhan (30an) tahun sebelum itu, tidak ada pemikiran dan karya Ekonom Muslim dan Ulama Indonesia yang membahas isu ekonomi syariah internasional tersebut. Banyak Ekonom Muslim dan Ulama Indonesia yang memegang kekuasaan bahkan sejak tahun 1970 yang mensikapi hal itu. Karena mereka punya pandangan dan pendirian yang tidak sependapat dengan isu dunia Muslim. Pada prinsipnya, mereka mengakui 
keharaman riba sifatnya mutlak sama dengan pengakuan mayoritas ulama dunia, karena keharaman riba merupakan "ajaran syariah.” Akan tetapi mereka tidak mengharamkan bunga bank yang normal, karena hal itu bukan termasuk perbuatan riba. Antara lain mereka yang berpandangan demikian adalah KH. A. Hasan (Hasan, 1975: 48), Kasman Singodimejo, Syafrudin Prawiranegara (Prawiranegara, 1988), Muhammad Hatta (Hatta, 1958, jilid II: 203), dan yang lainnya.

Berikut tabel seputar sejarah permulaan kemunculan lembaga ekonomi syariah di Indonesia (http://www.scribd.com/doc/53721584/Makalah-pinbuk: 12):

Tabel 1

\begin{tabular}{|c|c|c|c|c|}
\hline \multicolumn{5}{|c|}{$\begin{array}{c}\text { SEJARAH PERMULAAN } \\
\text { KEMUNCULAN LEMBAGA EKONOMI SYARIAH } \\
\text { DI INDONESIA }\end{array}$} \\
\hline No & Tanggal & $\begin{array}{l}\text { Nama/ } \\
\text { Tempat }\end{array}$ & $\begin{array}{l}\text { Latar Belakang } \\
\text { Agama Sosial } \\
\text { Politik Ekonomi }\end{array}$ & Keterangan \\
\hline 01 & 1992 & $\begin{array}{c}\text { Bank } \\
\text { Muamalat } \\
\text { Indonesia } \\
\text { (BMI)/ } \\
\text { Jakarta } \\
\end{array}$ & $\begin{array}{l}\text { Atas dukungan } \\
\text { politik pemerintah } \\
\text { orde baru, Soeharto }\end{array}$ & $\begin{array}{l}\text { Didukung oleh perangkat } \\
\text { hukum UU. No. } 7 \text { Tahun } 1992 \\
\text { dan PP No. } 72 \text { Tahun } 1992\end{array}$ \\
\hline 02 & BMT & 1984/ & Ideologis-akademik & $\begin{array}{l}\text { Sejarah BMT ada di Indonesia, } \\
\text { dimulai tahun } 1984 \\
\text { dikembangkan mahasiswa ITB } \\
\text { di Masjid Salman yang mencoba } \\
\text { menggulirkan lembaga } \\
\text { pembiayaan berdasarkan syariah } \\
\text { bagi usaha kecil. Kemudian } \\
\text { BMT lebih di berdayakan oleh } \\
\text { ICMI sebagai sebuah gerakan } \\
\text { yang secara operasional } \\
\text { ditindaklanjuti oleh Pusat } \\
\text { Inkubasi Bisnis Usaha Kecil } \\
\text { (PINBUK). }\end{array}$ \\
\hline 03 & $\begin{array}{l}13 \\
\text { Maret } \\
1995\end{array}$ & $\begin{array}{l}\text { PINBUK } \\
\text { (Pusat } \\
\text { Inkubasi } \\
\text { Usaha }\end{array}$ & $\begin{array}{l}\text { Latar belakang politik } \\
\text { ekonomi. Didirikan } \\
\text { oleh Organisasi } \\
\text { Masyarakat (Ormas) }\end{array}$ & $\begin{array}{l}\text { PINBUK bertugas mendirikan } \\
\text { BMT (Baitul mal wat-Tamwiil) } \\
\text { yang sekarang berbadan hukum } \\
\text { koperasi. Dalam periode } 1 \\
\text { dasawarsa pertama } 1995-2005\end{array}$ \\
\hline
\end{tabular}




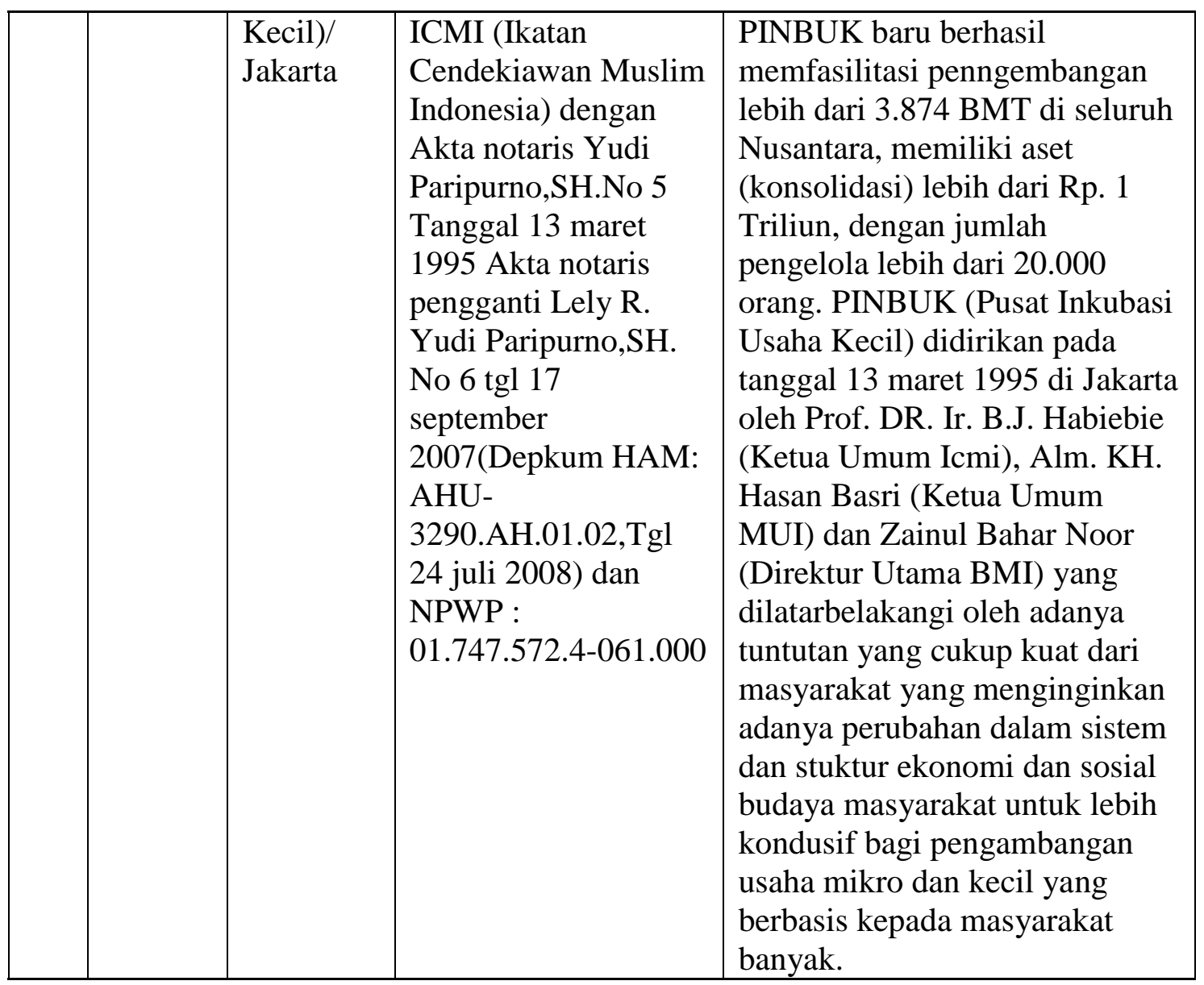

Pada masa Orde Barulah, Bank Syariah di Indonesia muncul, yaitu 1992. Diawali dengan berdirinya Bank Muamalat Indonesia (BMI) di mana Soeharto memiliki saham yang cukup besar serta Bank-bank Perkreditan Rakyat Syariah (BPRS). Namun, pada dekade hingga tahun 1998, perkembangan bank syariah boleh dibilang agak lambat. Pasalnya, sebelum terbitnya UU No. 10 Tahun 1998 tentang Perbankan, tidak ada perangkat hukum yang mendukung sistem operasional bank syariah kecuali UU No. 7 Tahun 1992 dan PP No. 72 Tahun 1992.

Berdasarkan UU No. 7 Tahun 1992 itu bank syariah dipahami sebagai bank bagi hasil. Selebihnya bank syariah harus tunduk kepada peraturan perbankan umum yang berbasis konvensional. Karenanya manajemen bank-bank syariah cenderung mengadopsi produk-produk perbankan konvensional yang “disyariatkan.” Dengan variasi produk yang terbatas. Akibatnya, tidak semua keperluan masyarakat terakomodasi dan produk yang ada tidak kompetitif terhadap semua produk bank 
konvensional. Setelah BMI berdiri pada tahun 1992, kemudian berdirilah Bank Syariah Mandiri (BSM), BNI Syariah, Bank IFI Syariah, dan Bank Mega Syariah.

Berikut data statistik perkembangan Bank Syariah per Maret 2011:

Tabel 2

\begin{tabular}{|c|c|c|c|c|c|c|c|c|c|c|c|c|c|c|c|c|c|c|c|}
\hline \multicolumn{20}{|c|}{ Tabel 1. Jaringan Kantor Perbankan Syariah (Islamic Banking Network) } \\
\hline & \multirow{2}{*}{2005} & \multirow{2}{*}{2006} & \multirow{2}{*}{2007} & \multirow{2}{*}{2008} & \multirow{2}{*}{2009} & \multicolumn{4}{|l|}{2010} & \multicolumn{9}{|l|}{2011} & \\
\hline & & & & & & Sep & Odt & Nov & Dec & Jan & Feb & Mar & Apr & May & $\mathbf{J n}$ & Jul & Aug & Sep & \\
\hline $\begin{array}{l}\text { Bank } \\
\text { Umum } \\
\text { Syari ah }\end{array}$ & & & & & & & & & & & & & & & & & & & $\begin{array}{l}\text { Islamic } \\
\text { Commercial } \\
\text { Bank }\end{array}$ \\
\hline $\begin{array}{l}\text { - Juml ah } \\
\text { Kantor }\end{array}$ & 304 & 349 & 401 & 581 & 711 & $\begin{array}{l}1,15 \\
1\end{array}$ & $\begin{array}{l}1,15 \\
4\end{array}$ & $\begin{array}{l}1,17 \\
1\end{array}$ & $\begin{array}{l}1,21 \\
5\end{array}$ & $\begin{array}{l}1,30 \\
9\end{array}$ & $\begin{array}{l}1,30 \\
8\end{array}$ & $\begin{array}{l}1,31 \\
1\end{array}$ & $\begin{array}{l}1,32 \\
6\end{array}$ & $\begin{array}{l}1,33 \\
2\end{array}$ & $\begin{array}{l}1,33 \\
2\end{array}$ & $\begin{array}{l}1,33 \\
2\end{array}$ & $\begin{array}{l}1,33 \\
2\end{array}$ & $\begin{array}{l}1,34 \\
9\end{array}$ & $\begin{array}{l}\text { - Number of } \\
\text { Offices }\end{array}$ \\
\hline $\begin{array}{l}\text { Unit } \\
\text { Usaha } \\
\text { Syariah }\end{array}$ & & & & & & & & & & & & & & & & & & & $\begin{array}{l}\text { Islamic } \\
\text { Business } \\
\text { Unit }\end{array}$ \\
\hline $\begin{array}{l}\text { - Jumlah } \\
\text { Kantor } \\
\text { Bank } \\
\text { Pembia } \\
\text { yaan } \\
\text { Rakyat } \\
\text { Syariah }\end{array}$ & 154 & 183 & 196 & 241 & 287 & 237 & 237 & 239 & 262 & 298 & 298 & 300 & 300 & 300 & 300 & 300 & 300 & 300 & $\begin{array}{l}\text { - Number } \\
\text { of Offices } \\
\text { Islamic } \\
\text { Rural } \\
\text { Bank }\end{array}$ \\
\hline $\begin{array}{l}\text { - Jumlah } \\
\text { Bank }\end{array}$ & 92 & 105 & 114 & 131 & 138 & 146 & 148 & 149 & 150 & 151 & 151 & 152 & 153 & 153 & 154 & 155 & 154 & 154 & $\begin{array}{l}\text { - Number } \\
\text { of Banks }\end{array}$ \\
\hline $\begin{array}{l}\text { - Jumlah } \\
\text { Kantor }\end{array}$ & 92 & 105 & 185 & 202 & 225 & 278 & 278 & 283 & 286 & 290 & 291 & 292 & 299 & 299 & 300 & 300 & 362 & 362 & $\begin{array}{l}\text { - Number } \\
\text { of Offices }\end{array}$ \\
\hline Total & 55 & 63 & 78 & 1,0 & 1,2 & 1,6 & 1,6 & 1,6 & 1,7 & 1,8 & 1,8 & 1,9 & 1,9 & 1,9 & 1,9 & 1,9 & 1,9 & 2,0 & Total \\
\hline Kantor & 0 & 7 & 2 & 24 & 23 & 66 & 69 & 93 & 63 & 97 & 97 & 03 & 25 & 31 & 32 & 32 & 94 & 11 & Number of \\
\hline
\end{tabular}




\begin{tabular}{|l|l|l|l|l|l|l|l|l|l|l|l|l|l|l|l|l|l|l|l|}
\hline & & & & & & & & & & & & & & & & & & & Offices \\
\hline
\end{tabular}

Keterangan: Sumber Statistik Perbankan Syariah (Islamic Banking Statistics) September 2011, Bank Indonesia

Berdasarkan data di atas, perkembangan Perbankan Syariah dan BMT sungguh sangat pesat di Indonesia. Sehingga kedua lembaga tersebut memerlukan disiplin manajemen keuangan syariah. Saat ini, manajemen keuangan syariah makin dikenal oleh masyarakat Indonesia, mungkin fenomena ini muncul berjalan seiring dengan kesadaran masyarakat akan kebutuhan penerapan syariah dalam kegiatan keuangan atau tergerak dengan maraknya pertumbuhan perbankan syariah.

Sejak 1991, tepatnya sejak berdirinya Bank Muamalat Indonesia (BMI) yang berlatar belakang "politik ekonomi" tersebut, perkembangan lembaga-lembaga ekonomi dan keuangan yang prinsip-prinsip oprasionalnya berdasarkan pada Syariah (Islam) telah melaju dengan cepat dengan akselerasi yang luar biasa. Hal ini ditandai dengan semakin bermunculan lembaga-lembaga ekonomi dan keuangan syariah, selain BMI, pada 1995 berdiri pula Asuransi Tafakul Indonesia (ATI) yang prinsip oprasionalnya sama dengan BMI yakni prinsip Syariah. perkembangan ini semakin semarak lagi ketika sat ini bermunculan Bank Perkreditan Syariah (BPRS) dan Baitul Mal wat-Tamwil (BMT). Semakin signifikan perkembangan lembaga ekonomi keuangan syariah ini, ketika beberapa bank konvensional mulai mendirikan unit usaha bank berdasarkan Syariah.

Indonesia sebagai salah satu Negara yang memiliki penduduk Muslim terbesar terlepas dari berbagai variasi pemikiran dan praktik keagamaan juga memiliki sejarah yang begitu panjang menentukan arah maju mundurnya kehidupan kebangsaan. Beberapa catatan sejarah bangsa ini mulai dari masa kolonial sampai sekarang, menunjukkan bahwa pilihan penjajahan baik secara militeristik maupun kolonialisasi pemikiran dan kebudayaan mengarah pada dan mengincar penggalian potensi ekonomi yang dimiliki negara ini. Fakta terbanyak yang menunjukkan bahwa kekuatan militer juga mengontrol kehidupan ekonomi melalui pengendalian pasar dan perusahaan-perusahaan besar yang ada di Indonesia.

Tetapi menurut pandangan pengkaji ekonomi syariah di perguruan tinggi, perkembangan lembaga ekonomi dan keuangan syariah ini tidak dibarengi dengan 
ketersediaan Sumber Daya Manusia dari alumni perguruan tinggi yang telah meluluskan sarjana ekonomi Islam. Sehingga dipahami bahwa Sumber Daya Manusia yang memiliki integritas, kualitas, dan kompetensi dalam lembaga ekonomi dan keuangan syariah ini masih sangat terbatas. Bahkan, saat ini rekrutmen tenaga kerja di lembaga ekonomi dan keuangan syariah terasa sangat dilematis. Sebab, lembaga pendidikan-pendidikan yang ada, Fakultas Ekonomi di Perguruan Tinggi Umum (PTU) dan Muamalah di Perguruan Tinggi Agama Islam (PTAI), tidak cukup mampu dalam memenuhi kebutuhan tenaga kerja di lembaga keuangan syariah. Namun kritik ini bernuansa "politik" dan merupakan "otokritik" terhadap dalih bank syariah dan akademisi syariah yang berpandangan bahwa faktor penghambat perkembangan keuangan syariah di Indonesia adalah sosialisasi ekonomi syariah oleh kalangan Muslim yang sangat kurang.

Bernuansa "politik", karena ada motif supaya alumni PTAI dengan bidang studi ekonomi syariah diterima di Bank atau berbagai lapisan masyarakat yang mempraktekkan keuangan syariah. Produk Fakultas Ekonomi di Perguruan Tinggi Umum (PTU) banyak paham tentang manajemen ekonomi dan keuangan, tetapi tidak banyak paham mengenai syariah (Fiqh al-Mu'amalah/Fikih Mu'amalah), sedangkan produk jurusan Muamalah di Perguruan Tinggi Agama Islam (PTAI), banyak paham Syariah (Fiqh al-Mu'amalah/Fikih Mu'amalah), tetapi tidak banyak paham tentang ekonomi dan keuangan.

Di samping itu, juga bersifat "otokritik", karena usulan di atas disampaikan oleh akademisi ekonomi syariah sebagai kritik bahwa dalih itu masih saja ditegaskan atas keadaan situasi masyarakat yang telah berinteraksi dengan ekonomi syariah. Biasanya dalih mereka akan ditambahi bahwa perkembangan ekonomi syariah di Indonesia bahkan di dunia, masih sangat muda dibanding ekonomi konvensional dengan bank konvensionalnya. Mereka tidak berfikir bahwa ada kerapuhan dan kelemahan mendasar dalam pengetahuan dan aplikasi ekonomi syariah.

\section{Konteks Sistem Keuangan Syariah di Indonesia}

Sebagaimana di negara Muslim lain, di Indonesia lembaga keuangan syariah berkembang sangat pesat. Mulai dari pengakuan legalitas perbankan syariah, kemudian muncullah koperasi syariah dengan nama BMT maupun bukan, asuransi 
syariah, pasar modal syariah, obligasi syariah, leasing syariah, pegadaian syariah. Lembaga-lembaga tersebut merupakan fenomena baru dan menarik dalam bisnis keuangan modern di Indonesia. Sekitar 20-an tahun ini. Keberadaannya menyumbangkan peranan penting dalam kebangkitan perekonomian bangsa, meskipun market share-nya belum begitu signifikan terhadap perkembangan keuangan konvensional.

Namun dari perkembangan perbankan syariah khususnya, ada beberapa hambatan yang muncul dari realitas perkembangan industri keuangan syariah di Indonesia: 1) Tingkat pemahaman dan pengetahuan umat tentang bank syariah masih sangat rendah; 2) Belum ada gerakan bersama dalam skala besar untuk mempromosikan bank syariah khususnya dan lembaga keuangan syariah pada umumnya; 3) Terbatasnya pakar dan SDM ekonomi syariah; 4) Peran pemerintah masih kecil dalam mendukung dan mengembangkan ekonomi syariah; 5) Peran ulama, ustad, dan da'i masih relatif kecil; 6) Peran akademisi di perguruan tinggi, termasuk perguruan tinggi Islam belum optimal; 7) Peran ormas Islam juga belum optimal dalam membantu dan mendukung gerakan lembaga keuangan syariah; 8) Anggapan dan sikap masyarakat yang telah berinteraksi dengan sistem ekonomi syariah bahwa fungsi lembaga ekonomi syariah sama halnya dengan fungsi lembagalembaga keuangan yang lain. Artinya preferensi masyarakat terhadap lembaga keuangan syariah dalam masyarakat Muslim merupakan persoalan yang tak terhindarkan. Preferensi itu adalah realitas sesudah sosialisasi ekonomi syariah selama 20-an tahun dan setelah dilahirkannya para sarjana ekonomi syariah baik dari Perguruan Tinggi Islam maupun dari Perguruan Tinggi Umum (Minhaji dalam Udovitch, 2008: xix). Preferensi ini juga merupakan konsekuensi logis seiring dengan ideologi ekonomi syariah bahwa lembaga keuangan syariah didirikan supaya berlaku secara umum dan tidak hanya untuk kalangan Muslim.

\section{Pengertian GCG}

Pengertian Good Corporate Governance (GCG) menurut World Bank, adalah kumpulan hukum, peraturan, dan kaidah-kaidah yang wajib dipenuhi yang dapat mendorong kinerja sumber-sumber perusahaan bekerja secara efisien, menghasilkan nilai ekonomi jangka panjang yang berkesinambungan bagi para pemegang saham 
maupun masyarakat sekitar secara keseluruhan. Dari hasil Workshop tentang $G C G$ di Kantor Meneg PM BUMN Desember 1999, dirumuskan bahwa Good Corporate Governance (GCG) berkaitan dengan pengambilan keputusan yang efektif yang bersumber dari budaya perusahaan, etika, nilai, sistem, proses bisnis, kebijakan, dan struktur organisasi yang bertujuan untuk mendorong dan mendukung pengembangan perusahaan, pengelolaan sumberdaya dan resiko secara lebih efisien dan efektif serta pertanggungjawaban perusahaan kepada pemegang saham dan stakeholders lainnya. Perlu diingatkan di sini, bahwa gagasan GCG muncul karena terancamnya kepentingan pemilik saham sebagai akibat kemelut agency problem, yaitu masalah pemisahan kepemilikan dan pengelolaan perusahaan (Basri dan Munandar, 2009: 233). Banyak perusahaan besar dijalankan oleh para profesional yang tidak memiliki atau memiliki sedikit saham perusahaan yang bersangkutan. Pemisahan ini membuat manajer merasa tidak memiliki perusahaan yang kemudian melakukan moral hazard untuk bertindak tidak sejalan dengan kepentingan pemegang saham akan tetapi bertindak atas kepentingan sendiri. Disamping itu, isu GCG tidak bisa dilepaskan dari isu Good and Clean Government.

Corporate Governance adalah proses dan struktur yang diterapkan dalam menjalankan perusahaan, dengan tujuan akhir meningkatkan nilai/keuntungan pemegang saham (shareholders) dengan sedapat mungkin memerhatikan kepentingan semua pihak yang terkait (stakeholders). Penerapan Good Corporate Governance harus dimulai: Pertama, pembenahan struktur dan sistem pengelolaan melalui pemberdayaan organ-organ perusahaan itu sendiri, yaitu Rapat Umum Pemegang Saham (RUPS), Komisaris, dan Direktur. Kedua, upaya perusahaan supaya dapat mengakomodasikan kepentingan-kepentingan stakeholders yang mencakup dua kelompok, yaitu primary stakeholders (stakeholders utama) dan secondary stakeholders (stakeholders kedua) (Basri dan Munandar, 2009: 233). Stakeholders Utama terdiri dari para pemegang saham dan investor, karyawan dan manajer, pelanggan, pemasok dan rekanan bisnis serta masyarakat setempat. Sedangkan Stakeholders Kedua terdiri dari pemerintah, masyarakat umum khususnya yang berkaitan dengan perusahaan, institusi umum, lembaga swadaya masyarakat $(N G O)$, media, akademisi, kelompok asosiasi bisnis dan pesaing (Basri dan 
Munandar, 2009). Dengan demikian, masalah GCG bukan hanya masalah peningkatan laba perusahaan, nilai saham di bursa, dan memberikan deviden yang sebesar-besarnya kepada shareholders namun juga masalah bagaimana perusahaan dapat berkontribusi positif dan membina hubungan baik dengan para stakeholders.

Awal kemunculan gagasan perlunya tata kelola perusahaan yang baik (GCG) karena perusahaan yang paling besar, berada dibawah pemerintahan dan pemerintahan pada dasarnya adalah perusahaan besar yang harus dikelola dengan baik. Mengenai good and clean government, ada tiga hal pokok yang urgen untuk menciptakan good and clean government, yaitu: 1) Pemberantasan KKN (korupsi, kolusi, dan nepotisme); 2) Disiplin anggaran dan penghapusan dana nonbudgeter; 3) Peningkatan fungsi pengawasan.

Krisis perbankan di Indonesia yang dimulai akhir tahun 1997 bukan sematamata diakibatkan oleh krisis ekonomi, tetapi juga diakibatkan oleh belum dilaksanakannya good corporate governance dan etika yang melandasinya. Menurut Faisal Basri, krisis ekonomi Indonesia sejak bulan juli 1997 pada dasarnya disebabkan oleh kemelut utang jangka pendek perusahaan-perusahaan swasta besar yang lantas mengakibatkan guncangan pada kurs mata uang dan selanjutnya berdampak pada instabilitas perekonomian. Masih menurut Faisal Basri, kemelut utang jangka pendek itu sebenarnya diakibatkan oleh Bad Corporate Governance, yaitu pengelolaan perbankan yang tidak memperhatikan kepentingan shareholders dan stakeholders (Basri dan Munandar, 2009).

Oleh karena itu, usaha restrukturisasi dan rekapitalisasi yang bertujuan mengembalikan kepercayaan kepada dunia perbankan Indonesia baru dapat mempunyai dampak jangka panjang dan mendasar, jika disertai tiga tindakan penting lain yaitu: 1) Ketaatan terhadap prinsip kehati-hatian; 2) Pelaksanaan good corporate governance; 3) Pengawasan yang efektif dari Otoritas Pengawas Bank.

Pelaksanaan good corporate governance (GCG) sangat diperlukan untuk membangun kepercayaan masyarakat dan dunia internasional sebagai syarat mutlak bagi dunia perbankan untuk berkembang dengan baik dan sehat. Sehingga Bank for International Settlement (BIS) sebagai lembaga yang mengkaji terus menerus prinsip kehati-hatian yang harus dianut oleh perbankan, telah pula mengeluarkan Pedoman 
Pelaksanaan GCG bagi dunia perbankan secara internasional. Pedoman serupa dikeluarkan pula oleh lembaga-lembaga internasional lainnya. Berdasarkan pertimbangan di atas dan tingginya tingkat kompleksitas serta risiko bisnis perbankan, Komite Nasional Kebijakan Corporate Governance memandang perlu untuk mengeluarkan Pedoman Good Corporate Governance Perbankan Indonesia (Indonesian Banking Sector Code) sebagai pelengkap dan bagian tak terpisahkan dari Pedoman Umum GCG. Perbankan dalam pedoman ini meliputi bank umum dan BPR yang dijalankan secara konvensional maupun syariah.

Sebagai lembaga intermediasi dan lembaga kepercayaan, dalam melaksanakan kegiatan usahanya bank harus menganut prinsip keterbukaan (transparency), memiliki ukuran kinerja dari semua jajaran bank berdasarkan ukuran-ukuran yang konsisten dengan corporate values, sasaran usaha dan strategi bank sebagai pencerminan akuntabilitas bank (accountability), berpegang pada prudential banking practices dan menjamin dilaksanakannya ketentuan yang berlaku sebagai wujud tanggung-jawab bank (responsibility), objektif dan bebas dari tekanan pihak manapun dalam pengambilan keputusan (independency), serta senantiasa memperhatikan kepentingan seluruh stakeholders berdasarkan azas kesetaraan dan kewajaran (fairness). Dalam hubungan dengan prinsip tersebut bank perlu memperhatikan hal-hal sebagai berikut :

Jelasnya, GCG ditegakkan di atas prinsip-prinsip manajemen perusahaan. Ada banyak versi pendapat mengenai jumlah prinsip itu. Namun di sini dijelaskan pendapat yang mudah diikuti. Yaitu bahwa GCG ditegakkan dengan lima prinsip utama yaitu keterbukaan (transparency), akuntabilitas (accountability), tanggung jawab (responsibility), independensi (independency) serta kewajaran (fairness), yang diciptakan untuk dapat melindungi kepentingan semua pihak yang berkepentingan (stakeholders). Pengaturan dan implementasi GCG memerlukan komitmen dari "top management" dan "seluruh jajaran organisasi." Pelaksanaannya dimulai dari penetapan kebijakan dasar (strategic policy) dan kode etik yang harus dipatuhi oleh semua pihak dalam perusahaan. Bagi perbankan Indonesia, kepatuhan terhadap kode etik yang diwujudkan dalam satunya kata dan perbuatan, merupakan faktor penting sebagai landasan penerapan GCG. 
Penjelasan dari 5 prinsip GCG di atas sebagai berikut:

\section{A. Keterbukaan (Transparency);}

1. Bank harus mengungkapkan informasi secara tepat waktu, memadai, jelas, akurat dan dapat diperbandingkan serta mudah diakses oleh stakeholders sesuai dengan haknya.

2. Informasi yang harus diungkapkan meliputi tapi tidak terbatas pada hal-hal yang bertalian dengan visi, misi, sasaran usaha dan strategi perusahaan, kondisi keuangan, susunan dan kompensasi pengurus, pemegang saham pengendalian, cross shareholding, pejabat eksekutif, pengelolaan risiko (risk management), sistem pengawasan dan pengendalian intern, status kepatuhan, sistem dan pelaksanaan GCG serta kejadian penting yang dapat mempengaruhi kondisi bank.

3. Prinsip keterbukaan yang dianut oleh bank tidak mengurangi kewajiban untuk memenuhi ketentuan rahasia bank sesuai dengan peraturan perundang-undangan yang berlaku, rahasia jabatan, dan hak-hak pribadi.

4. Kebijakan bank harus tertulis dan dikomunikasikan kepada pihak yang berkepentingan (stakeholders) dan yang berhak memperoleh informasi tentang kebijakan tersebut.

\section{B. Akuntabilitas (Accountability);}

1. Bank harus menetapkan tanggung jawab yang jelas dari masing-masing organ organisasi yang selaras dengan visi, misi, sasaran usaha dan strategi perusahaan.

2. Bank harus meyakini bahwa semua organ organisasi bank mempunyai kompetensi sesuai dengan tanggung jawabnya dan memahami perannya dalam pelaksanaan GCG.

3. Bank harus memastikan terdapatnya check and balance system dalam pengelolaan bank.

4. Bank harus memiliki ukuran kinerja dari semua jajaran bank berdasarkan ukuranukuran yang disepakati konsisten dengan nilai perusahaan (corporate values), sasaran usaha dan strategi bank serta memiliki rewards and punishment system.

\section{Tanggung Jawab (Responsibility);}


1. Untuk menjaga kelangsungan usahanya, bank harus berpegang pada prinsip kehati-hatian (prudential banking practices) dan menjamin dilaksanakannya ketentuan yang berlaku.

2. Bank harus bertindak sebagai good corporate citizen (perusahaan yang baik) termasuk peduli terhadap lingkungan dan melaksanakan tanggung jawab sosial.

\section{Independensi (Independency);}

1. Bank harus menghindari terjadinya dominasi yang tidak wajar oleh stakeholder manapun dan tidak terpengaruh oleh kepentingan sepihak serta bebas dari benturan kepentingan (conflict of interest).

2. Bank dalam mengambil keputusan harus obyektif dan bebas dari segala tekanan dari pihak manapun.

\section{E. Kewajaran (Fairness);}

1. Bank harus senantiasa memperhatikan kepentingan seluruh stakeholders berdasarkan azas kesetaraan dan kewajaran (equal treatment).

2. Bank harus memberikan kesempatan kepada seluruh stakeholders untuk memberikan masukan dan menyampaikan pendapat bagi kepentingan bank serta mempunyai akses terhadap informasi sesuai dengan prinsip keterbukaan.

Dalam ajaran Islam, poin-poin tersebut menjadi prinsip penting dalam aktivitas dan kehidupan seorang muslim. Islam sangat intens mengajarkan diterapkannya prinsip 'adalah (keadilan), tawazun (keseimbangan), mas'uliyah (akuntabilitas), akhlaq (moral), shiddiq (kejujuran), amanah (pemenuhan kepercayaan), fathanah (kecerdasan), tabligh (transparansi, keterbukaan), hurriyah (independensi dan kebebasan yang bertanggungjawab), ihsan (profesional), wasathan (kewajaran), ghirah (militansi syariah, militansi syariah, idarah (pengelolaan), khilafah (kepemimpinan), aqidah (keimanan), ijabiyah (berfikir positif), raqabah (pengawasan), qira'ah dan ishlah (organisasi yang terus belajar dan selalu melakukan perbaikan). Berdasarkan uraian di atas dapat dipastikan bahwa Islam jauh mendahului kelahiran GCG (Good Coorporate Governance) yang menjadi acuan bagi tata kelola perusahaan yang baik di dunia. Prinsip-prinsip itu diharapkan dapat 
menjaga pengelolaan institusi ekonomi dan keuangan syariah secara profesional dan menjaga interaksi ekonomi, bisnis dan sosial berjalan sesuai dengan aturan permainan dan best practice yang berlaku.

Praktek moral hazard sudah menjadi kebiasaan di lembaga-lembaga perbankan. Kita sering mendengar berita korupsi di berbagai lembaga perbankan, baik bank BUMN maupun bank swasta. Berbagai kejadian korupsi tersebut, harus menjadi perhatian serius bagi para stakeholders bank syariah, baik pemilik/ pemegang saham, komisaris, direksi, karyawan (kru,) Dewan Pengawas Syariah, nasabah dan para akademisi ekonomi syariah lainnya.

Di masa depan, kemungkinan terjadinya korupsi dan penyimpangan di bank syariah merupakan hal tidak mustahil, meskipun di situ ada Dewan Pengawas Syariah, karena para pelakunya bukan malaikat. Apalagi sekarang ini perbankan syariah semakin banyak, maka para bankir syariah pun semakin bertambah banyak pula. Sehubungan dengan itu para jajaran eksekutif dan pejabat bank, bahkan termasuk komisaris harus ekstra hati-hati dalam mengelola lembaga perbankan syariah yang selalu dinilai "suci", karena berasal dari prinsip ilahiyah. Harus dimaklumi, bahwa simbol agama tidak menjamin sebuah lembaga menjadi bersih dari perilaku korupsi. Karena oknum seringkali tergoda oleh harta dunia. Departemen Agama misalnya saat ini sedang diincar oleh tim BPK sehubungan dengan dugaan adanya penyimpangan di bidang urusan haji. Sebelum terjadinya kasus yang bisa mencoreng lembaga syariah, maka sejak dini perlu diingatkan kepada pihak-pihak terkait agar berkomitmen menjauhi setiap penyimpangan di bank syariah. 
Dalam konteks ini, Dhani Gunawan, peneliti senior Bank Indonesia, menyatakan bahwa korupsi di lembaga perbankan pada umumnya dapat menjelma dalam tiga bentuk. Pertama, bentuk langsung, Kedua, tidak langsung dan Ketiga, samar-samar (fuzzy). Bentuk korupsi langsung adalah pencurian uang pada bank oleh oknum individu atau kelompok dengan cara memanipulasi laporan keuangan, manipulasi dokumen dana bank atau dana nasabah, juga bisa dalam bentuk me-markup pembelian barang atau inventaris.

Korupsi tidak langsung dapat berwujud dalam nepotisme tender barang atau jasa kepada sanak keluarga, sehingga bank dapat menjadi rugi, karena kualitas barang/jasa yang rendah. Atau oknum bankir mendapat komisi, atau sukses fee dari rekanan bank yang tidak dibukukan sebagai laba bank. Dana yang tak dibukukan ini diistilahkan dengan "dana taktis". Keberadaan dana taktis ini merupakan bibit awal korupsi, bibit awal rekayasa giant mark-up, karena dana taktis itu berasal dari anggaran bank yang kemudian berubah menjadi dana kepentingan pribadi atau oknum.

Bentuk korupsi lainnya ialah seperti nepotisme penyaluran kredit yang mengurangi potensi pendapatan bank, nepotisme penerimaan pegawai atau promosi pegawai. Hal ini dapat menzalimi orang lain yang lebih baik, berkualitas dan lebih berhak.

Sedangkan korupsi samar-samar merupakan bentuk yang paling potensial sering terjadi, karena berada di area abu-abu yang mudah disembunyikan, seperti komisaris atau direksi yang menggunakan mobil dinas mewah yang kemudian setelah penyusutan lalu dibeli menjadi miliknya dengan harga di bawah pasar. Contoh berikutnya adalah menggunakan fasilitas asuransi jabatan yang berlebihan, mendapatkan bonus yang melebihi batas kewajaran, mendapatkan pendapatan tambahan yang ditutupi dengan label success fee, atau pegawai yang sering mankir dari tugas dengan berbagai alasan.

Semua bentuk korupsi, baik langsung, tidak langsung maupun samar-samar adalah korupsi yang harus diberantas dengan aturan GCG (Good Corporate Governance) yang jelas. Karena itu, lembaga pengawasan, lembaga audit, dan masyarakat, harus tetap kritis terhadap bank syariah. Jangan terpana dengan label 
syariah, karena bisa saja lembaga memakai label syariah tetapi prakteknya tidak sepenuhnya syariah.

Dalam konteks penerapan GCG di bank syariah, para bankir syariah, harus benar-benar merujuk kepada prinsip-prinsip dan nilai-nilai ekonomi dan bisnis Islam yang telah diterapkan oleh Rasulullah. Kalau tidak, jangan menjadi praktisi bankir syariah karena dikhawatirkan mereka hanya akan merusak citra "kesucian" syariah di masa yang akan datang.

Nabi Muhammad adalah pelopor penegakan moral dalam setiap aspek kehidupan. Ia bersabda, "Sesungguhnya aku diutus untuk menyempurnakan akhlak". Prinsip-prinsip dan nilai-nilai bisnis yang diajarkan dan dipraktekan Nabi Muhammad Saw tersebut sangat identik dengan spirit GCG yang dikembangkan saat ini.

Perbedaan GCG syariah dan konvensional terletak pada syariah compliance yaitu kepatuhan pada prinsip-sprinsip syariah untuk perbankan. Sedangkan prinsipprinsip transparansi, kejujuran, kehati-hatian, kedisiplinan merupakan prinsip universal yang juga terdapat dalam aturan GCG konvensional.

\section{Prinsi-prinsip Manajemen Keuangan Syariah}

Manajemen berarti suatu proses perencanaan, pengorganisasian, pengkoordinasian, dan pengontrolan sumber daya untuk mencapai sasaran (goals) secara efektif dan efesien. Manajemen keuangan adalah aktivitas perusahaan yang berhubungan dengan bagaimana memperoleh dana, menggunakan dana, dan mengelola aset sesuai dengan tujuan perusahaaan secara menyeluruh. Dengan kata lain, manajemen keuangan adalah suatu kegiatan perencanaan, penganggaran, pemeriksaan, pengelolaan, pengendalian, pencarian dan penyimpanan dana yang dimiliki oleh organisasi atau perusahaan. Manajemen keuangan adalah manajemen dana baik yang berkaitan dengan pengalokasian dana dalam berbagai bentuk investasi secara efektif maupun usaha pengumpulan dana untuk pembiayaan investasi atau pembelanjaan secara efisien (Sartono, 2010: 6).

Meskipun fungsi manajer keuangan pada setiap perusahaan belum tentu sama, namun pada prinsipnya fungsi utamanya tetap sama. Demikian juga manajemen 
keuangan untuk perbankan. Keputusan alokasi dana mencakup baik dana yang berasal dari dalam perusahaan dan luar perusahaan pada berbagai bentuk investasi (Sartono, 2010: 6). Inti persolannya adalah investasi macam apa yang paling baik bagi perbankan. Sedangkan keputusan investasi secara garis besar terdiri dari dua jenis, yaitu pertama berupa investasi jangka pendek seperti investasi dalam kas, persediaan, piutang, dan surat berharga dan kedua berupa investasi jangka panjang dalam bentuk gedung, peralatan produksi, tanah, kendaraan, dan aktiva tetap lainnya. Keputusan invetasi ini akan tercermin pada sisi aktiva dalam neraca perusahaan. Seorang direksi bank bertanggung jawab menentukan perimbangan yang optimal untuk setiap jenis aset bank.

Untuk memahami manajemen keuangan dan implementasinya di suatu perusahaan, adalah penting untuk memahami apa sesungguhnya yang menjadi tujuan perusahaan. Banyak pihak berpendapat bahwa tujuan suatu perusahaan adalah untuk memaksimumkan laba. Namun demikian memaksimumkan laba dinilai kurang tepat sebagai pedoman dalam pengambilan keputusan di bidang keuangan. Hal ini karena: 1) Memaksimumkan laba tidak memperhatikan dimensi waktu; 2) Terminologi laba mempunyai pengertian ganda, disebabkan terdapat banyak pengertian laba (laba kotor, laba operasi, laba bersih dan sebagainya); 3) Memaksimumkan laba tidak memperhatikan faktor risiko; 4) Memaksimumkan laba tidak memperhatikan tanggung jawab sosial.

Mengingat tujuan memaksimumkan laba dinilai kurang tepat sebagai dasar pengambilan keputusan di bidang keuangan, para pakar di bidang keuangan merumuskan tujuan normatif suatu perusahaan adalah: "untuk memaksimumkan nilai perusahaan atau kekayaan bagi pemegang saham, yang dalam jangka pendek bagi perusahaan yang sudah go public tercermin pada harga pasar saham perusahaan yang bersangkutan di Pasar Modal."

Lebih jauh, bagaimana hubungan antara fungsi keuangan dengan tujuan perusahaan dapat digambarkan sebagai berikut:

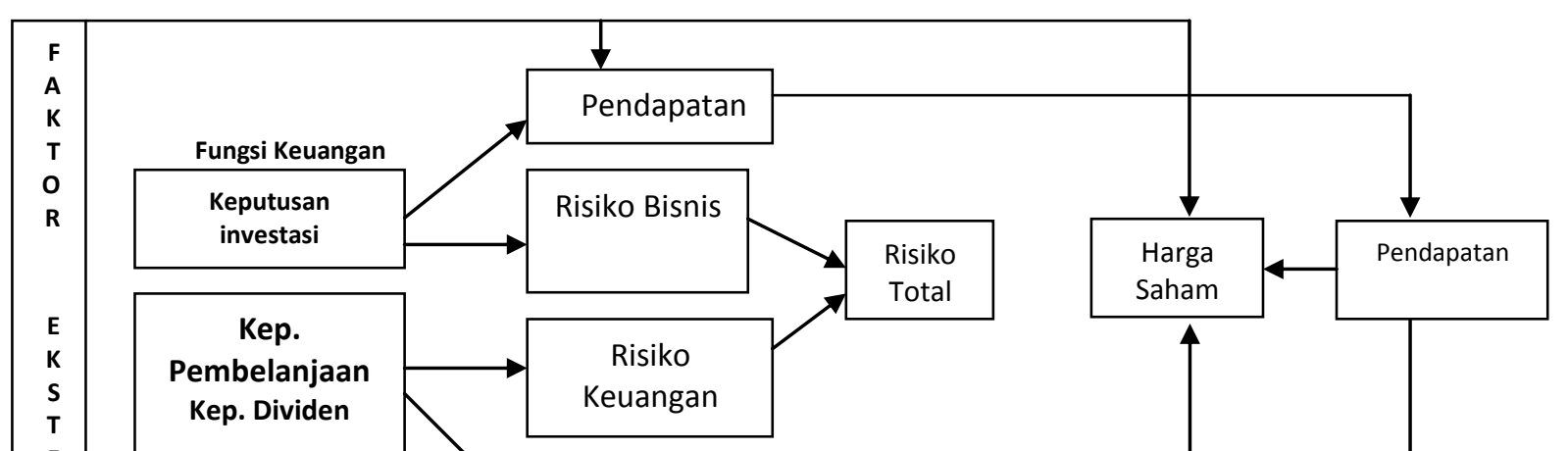


Dari gambar di atas tampak bahwa, faktor intern perusahaan, dalam hal ini adalah fungsi keuangan akan mempengaruhi pendapatan dan risiko. Dalam situasi yang tidak pasti pendapatan dan risiko harus dipertimbangkan pada setiap keputusan di bidang keuangan.

Dari penjelasan di atas, di sini dirumuskan tolak ukur/indikator keberhasilan dalam manajemen keuangan yang sesuai dengan Islam dan ciri khas Bank Syariah. Indikator keberhasilannya berupa proses-hasil dalam melakasanakan nilai-nilai yang dibutuhkan perbankan syariah. Lebih lanjut, indikator keberhasilan itu, menurut penulis, berbentuk rangkaian-nilai utama yang relevan dengan sistem perbankan syariah. Kemudian hal itu mesti diterapkan seiring dengan praktik manajemen keuangan serta disiplin ilmu yang lain. Nilai-nilai tersebut adalah sebagai berikut:

1. Capaian keuntungan dengan cara yang benar, yaitu mencakup cara-cara: (1) tidak dengan cara menipu seperti dengan sengaja salah menimbang, salah menyukat, salah ukur dan lain-lain [Al-An'am: 152-153, al-Muthoffifin: 112]; (2) tidak khianat atas janji atau sumpah yang baik [An-Nahl: 92-94]; (3) tidak mencuri [Surat Al-Maidah: 38]; (4) tidak berasal dari judi/maisir [Al-Baqoroh: 219, 280 serta Al-Maidah: 90-91]; (5) larangan menimbun untuk diri sendiri [At-Taubah: 34-35]; (6) tidak mengambil hak orang lain tanpa izin atau atas kemauan orang yang berhak [Al-Baqoroh: 188]; (7) tidak melalui cara "riba" untuk memperoleh keuntungan, yaitu cara transaksi yang salah dalam mencari keuntungan dan memenuhi keadaan menekan (zalim), baik secara kuantitas ataupun kualitas; (8) dan tanpa mengakibatkan kerusakan, antara lain terhadap sistem ekonomi pasar (Hud ayat $15-16)$;

2. Amanah/keadaan dapat dipercaya (trust) yang tinggi, antara lain dengan cara menepati janji dan menyerahkan pembagian penghasilan yang 'cukup' yang diterima baik dan tidak merugikan. Ketiganya tidak dapat dipisahkan dalam manajemen keuangan (QS an-Nisa': 58, 59, 84; asy-Syura: 38; Ali Imron: 159 dan tentang menepati janji An-Nahl: 92, 94). Kualitas 
kepercayaan manajemen keuangan dapat diukur dari sikapnya yang handal dan tangguh dalam menghadapi situasi strategis, dilematis, dan penuh resiko. Sehingga kepercayaan dari stakeholder dan shareholde akan tumbuh secara perlahan dan bertaham seiring dengan perkembangan keadaan krisis tersebut;

3. Kedermawanan terhadap manusia yang lemah dan tertindas ekonomisnya. (QS. Adz-Dzariyaat: 19; As-Sabaa: 31; Al-Baqarah; 254, 261, 275; ArRuum: 39 ; At-Taubah: 60). Hal ini dapat diwujudkan dalam bentuk pengambilan dana ZIS (Zakat, Infak, Shodaqoh) dari hasil usaha bank syariah ataupun bank syariah sebagai penerima dan pengelola dana ZIS.

\section{GCG dan Manajemen Keuangan Syariah untuk Kehandalan Perbankan Syariah}

Dengan memperhatikan kepentingan shareholder dan stakeholder perbankan syariah, permasalahan manajemen keuangan juga terjadi sangat kompleks. Tentu saja dalam konteks perbankan syariah, pertama-tama dari masalah manajemen keuangan itu adalah berasal dari sebab etis, yaitu masalah pelanggaran atau ketidakpatuhan perbankan syariah terhadap teori produk pendanaan-pembiayaan syariahnya serta prinsip-prinsip syariah yang lain dalam batasan ukuran dan signifikansi tertentu. Sehingga perusahaan terhambat dalam mencapai tujuan bisnis sesuai blue print perbankan syariah.

Akan tetapi kepatuhan terhadap nilai manajemen keuangan syariah sepenuhnya tidak berarti secara otomatis "menaikkan atau melejitkan" profitabilitas perbankan syariah. Perlu ada analisa yang lengkap, yaitu pembahasan tentang seberapa erat korelasi nilai-nilai yang dipatuhi itu dengan tujuan mendapatkan keuntungan bank syariah. Namun kita juga mengakui bahwa pelanggaran terhadap etika manajemen keuangan syariah dapat mengganggu pencapaian tujuan manajemen keuangan perbankan syariah, bahkan menggagalkannya. Hal ini terjadi karena manajemen keuangan perbankan syariah demikian juga perbankan konvensional menggunakan manusia yang bersifat etis sebagai salah satu faktor produksinya.

Jelasnya bahwa kebutuhan manusia bukan sekedar kebutuhan materi. Sehingga anggapan bahwa kebutuhan materi manusia itu dipahami sebagai kebutuhan materi 
perorangan adalah salah. Karena di samping kebutuhan materi dalam arti sempit dan luas, manusia juga punya kebutuhan sosial spiritual kultural. Namun perlu dicatat, dalam praktiknya, tidak ada perusahaan yang mengejar laba yang mengabaikan etika/moralitas sepenuhnya/secara absolut. Hanya saja, terjadinya ketimpangan ekonomi adalah karena pelanggaran atas etika mendasar terkait dengan kehidupan sosial, seperti dalam bentuk korupsi dan pelanggaran janji/aturan.

Dengan demikian, pelaksanaan Good Corporate Governance (GCG) pada perbankan syariah berdampak secara langsung memudahkan pelaksanaan manajemen keuangan syariahnya. GCG pada perbankan syariah adalah cerminan manajemen keuangan syariah yang konsisten, pada satu kemungkinan. Namun kemungkinan lainnya, GCG perbankan syariah berpotensi menjadi baju yang mempercantik tindakan-tindakan keuangan yang tidak konsisten baik akibat kekurangan teori dan praktik produk bank syariah maupun moral hazard top management dan anggota organisasinya. Sehingga aplikasi GCG hanya merupakan kewajiban. Jika GCG bank syariah mesti dilaporkan kepada otoritas perbankan dalam bentuk penjelasanpenjelasan tertulis, maka secara psikologis ada keenggana pihak bank dalam menunjukkan kekurangannya. Hal ini mungkin dianggap wajar, karenanya tidak heran jika ada tradisi pembukuan ganda dalam pelaporan keuangan. Sehingga pada intinya, manajemen keuangan syariah yang teraplikasikan merupakan daya kesadaran perbankan syariah untuk meraih kemajuan yang tidak semu.

Karena analisa manajemen keuangan yang sesuai dengan syariah, menawarkan kemungkinan penyelesaian atas problem keuangan bank syariah. Ketika menghadapi realitas preferensi nasabah, bank syariah tentu mencari alternatif keuangan yang bisa memberikan added-value dalam perjalanan organisasinya. Tawaran dari manajemen keuangan itu dapat berupa strategi dan pengetahuan normatif-liberatif. Pada tataran praktik, manajemen keuangan yang sesuai syariah menjadi landasan aksional dalam mensikapi krisis. Sampai di sini, kita memahami manajemen keuangan syariah bukan sekedar kumpulan aksioma normatif-keagamaan, yaitu berupa dalil-dalil, namun juga kumpulan aksioma normatif-sosial ekonomi termasuk yang ada di Indonesia. 


\section{Penutup}

Dari penjelasan di atas, kesimpulannya GCG bagi perbankan syariah dilakukan untuk meningkatkan kepercayaan masyarakat terhadap kinerja perbankan syariah. Dengan begitu, GCG diperlukan sekali bagi perbankan syariah. Namun kemudian pada tahap pelaporannya, GCG menghasilkan formalitas semu akibat problem finansial strategis yang bertabrakan dengan syariah complaiance. Kekurangan itu dapat dicari dengan menggali Manajemen Keuangan Syariah yang berorientasi untuk pengembangan Perbankan Syariah kedepan. Sehingga GCG pada perbankan syariah berfungsi meningkatkan efektivitas pelaksanaan fungsi Manajemen Keuangan Syariah. Sementara itu, pengetahuan Manajemen Keuangan Syariah perlu terus digali. Terlepas dari GCG dan Manajemen Keuangan Syariah yang lengkap dan dapat dapat diterapkan, semua sistem itu tidak dapat berfungsi sebagaimana tujuan penyusunannya jika tanpa mekanisme pengawasan yang efektif untuk menghilangkan kesemuan formalitas. 


\section{Daftar Pustaka}

Al-Zuhaili, Wahbah. 1997. Al-Fiqhu al-Islami wa Adillatuhu. juz. 3. Cet. 4. Beirut: Dar al-Fikr.

Basri, Faisal dan Haris Munandar. Lanskap Ekonomi Indonesia: Kajian dan Renungan terhadap Masalah-masalah Struktural, Transformasi Baru, dan Prospek Perekonomian Indonesia. Jakarta: Kencana, 2009.

Chapra, M. Umer. 2000. The Future of Economics: an Islamic Perspective. UK: Islamic Foundation.

Ghani, Ab. Mumin Ab. 1999. Sistem Kewangan Islam dan Pelaksanaannya di Malaysia. Kuala Lumpur: Jabatan Kemajuan Islam Malaysia.

Hanbal, Ahmad bin. t.t. Musnad al-Imam Ahmad bin Hanbal. Juz 1. Cet. 2. Beirut: Dar al-Kutub al-'Ilmiyyah.

Hasan, A. 1975. Riba: Beberapa Pembahasan Masalah Riba. Bangil: Penerbit Percetakan Persatuan.

Kamus Besar Bahasa Indonesia. 1989. Jakarta: Balai Pustaka. 1989.

Khan, Muhammad Akram. 1994. An Introduction to Islamic Economics, Islamabad: the International Institute of Islamic Thought \& Institute of Policy Studies.

Lewis, Mervin K. dan Lativa M. Algaoud. 2007. Perbankan Syariah: Prinsip, Praktik, dan Prospek, Jakarta: Serambi.

Minhaji, Akhmad. 2008. "Ekonomi dan Lembaga Keuangan Islam” dalam Abraham L. Udovitch, Kerjasama Syariah dan Bagi Untung-Rugi dalam Sejarah Islam Abad Pertengahan. Terj. Syafrudin Arif M.M. Kediri: Penerbit Qubah.

Prawiranegara, Syafruddin. 1988. Ekonomi dan Keuangan: Makna Ekonomi Islam, Jakarta: Haji Masagung.

Qureshi, Anwar Iqbal. 1961. Islam and The Theory of Interest. Ed. 2, Lahore: SH Muhammad Ashraf.

Saeed, Abdullah. 2003. Bank Islam dan Bunga. Terj. M. Ufuqul Mubin, Nurul Huda dan Ahmad Sahidah, Yogyakarta: Pustaka Pelajar.

Sartono, Agus. 2010. Manajemen Keuangan Teori dan Aplikasi, Yogyakarta: BPFE.

Siddiqi, Muhammad Iqbal. tt. Model of an Islamic Bank, Lahore: Kazi Publications. 